\author{
Łukasz WORDLICZEK \\ Uniwersytet Jagielloński \\ E-mail: lukasz.wordliczek@uj.edu.pl
}

\title{
POLITYKA ZAGRANICZNA PIERWSZYCH CZTERECH LAT PREZYDENTURY BARACKA OBAMY
}

\author{
KONTYNUACJA CZY ZMIANA?
}

\begin{abstract}
Barack Obama's Foreign Policy during His First Term. Continuation or Change?

The paper aims at assessing United States foreign policy during Barack Obama's first term in office. While acknowledging many possible conceptual frameworks, the author uses continuity and change approach. Thus, the following areas are covered: implementation of selected foreign policy decisions, personal dimension, relations with Congress and some projection for future development. Surprisingly, notwithstanding rhetoric of change, it seems to be evident that the United States foreign policy between 2009 and 2012 may be described with considerable amount of continuity.
\end{abstract}

KEY WORDS Barack Obama, US budget expenditures, United States Foreign Policy

[...] stawki przemian sa zwykle wysokie, rezultaty bardzo niepewne, a zdolność matych wktadów wptywania na wynik jest wielka ${ }^{1}$.

Koniec urzędowania jakiegoś polityka jest naturalnym impulsem do podsumowań. 1 Niewiele przy tym zmienia okoliczność, że w momencie rozpoczęcia pisania tego tekstu (wiosna 2012) przecież nie było wiadomo, czy przedmiotem takiego bilansu jest

I. Wallerstein, Koniec świata jaki znamy, przeł. M. Bilewicz, A.W. Jelonek, K. Tyszka, Warszawa 2004, s. 27, Spoteczeństwo Wspótczesne. 
tylko pierwsza, czy też zarazem jedyna kadencja Baracka Obamy². Faktem jest, że cztery lata urzędowania prezydenta stanowią pewną cezurę w amerykańskim życiu politycznym i stąd też można zastanowić się nad tytułowym zagadnieniem.

$\mathrm{Z}$ analitycznego punktu widzenia mamy do dyspozycji kilka perspektyw. Po pierwsze, podsumowanie urzędowania jakiegoś polityka i jego współpracowników może być dokonane przez pryzmat sukcesów i porażek. Jest to punkt widzenia tyleż powszechnie stosowany, co jednocześnie budzący kontrowersje. Sprowadzają się one w zasadzie do podstawowego dylematu: jak precyzyjnie - i jednocześnie obiektywnie - wskazać na sukcesy i porażki? Czy zawsze porażką jest niezrealizowanie zamierzeń, które często są formułowane ad hoc w ferworze kampanii wyborczej? Czy porażką jest niezrealizowanie jakiegoś deklarowanego postulatu, o którym wiadomo, że nie jest darzony szczególnym uznaniem opinii publicznej, środowiska politycznego czy też otoczenia międzynarodowego? I w końcu - czy każdy z oceniających zawsze tak samo będzie definiował sukces/porażkę danego przywódcy? Już choćby kilka powyższych pytań pozwala autorowi niniejszego tekstu poszukać klucza koncepcyjnego do przedmiotowej analizy gdzie indziej³

Być może warto zatem spojrzeć na pierwszą kadencję prezydenta USA przez pryzmat zagadnienia ciągłości i zmiany w ramach amerykańskiej polityki zagranicznej. Taka propozycja wydaje się atrakcyjna choćby z następujących względów:

- umożliwia prześledzenie, które elementy polityki pozostały - względnie - niezmienione, a które poddano modyfikacji, pozwala to na próbę analizy polityki zagranicznej USA w ciągu ostatnich czterech lat,

- może to stanowić punkt wyjścia do zmierzenia się z pytaniem odnośnie do kierunków polityki na najbliższe lata,

- hasło „zmiany” było powszechnie identyfikowanym lejtmotywem kampanii wyborczej Baracka Obamy; uczyniono z niego wręcz polityczne credo ówczesnego kandydata partii demokratycznej.

Nawet jeżeli powyższe argumenty są kontrowersyjne, to i tak przyjęcie proponowanej perspektywy pozbawia nas konieczności zmierzenia się z dylematami wskazanymi przy okazji oceniania sukcesów i porażek.

Tekst został zaktualizowany w listopadzie 2012 r., stosownie do zaistniałych wydarzeń.

3 Ewentualna próba zastosowania takiego ujęcia mogłaby zawierać się w następującym zestawieniu. Sukcesy: poprawa wizerunku USA na świecie, zakończenie działań militarnych w Iraku i Afganistanie, „nowe otwarcie” w stosunkach z Rosją i podpisanie nowego układu START, osłabienie potencjału Al-Kaidy, doprowadzenie do uchwalenia 9 czerwca 2010 r. przez Radę Bezpieczeństwa ONZ rezolucji nakładającej sankcje na Irak, względna skuteczność wobec wydarzeń w ramach „arabskiej wiosny”. Porażki: impas w sprawie konfliktu bliskowschodniego, brak efektów w działaniach na rzecz ochrony środowiska naturalnego, wciąż niskie notowania USA w świecie muzułmańskim, brak skutecznych działań wobec popadania Meksyku w otchłań anarchii charakterystycznej dla państw upadłych, rozwój programów nuklearnych Iranu i Korei Północnej, dalsze przetrzymywanie więźniów w Guantanamo, brak wyraźnej reakcji na tłumienie protestów w związku z wyborami w Iranie w czerwcu 2009 r., niezdecydowanie wobec sytuacji w Libii (o czym nieco szerzej w dalszej części tekstu). Powyższy katalog zagadnień przedstawiono głównie w oparciu o: M. Indyk, K. Lieberthal, M.E. O’Hanlon, Scoring Obama's Foreign Policy. A Progressive Pragmatist Tries to Bend History, „Foreign Affairs” 2012, May/ June, [on-line:] http://www.foreignaffairs.com/articles/137516/martin-indyk-kenneth-lieberthal-and-michael-e-ohanlon/scoring-obamas-foreign-policy, 3 VII 2012. 
Z konceptualnego punktu widzenia zastosowana analiza jest zainspirowana głównie teorią punctuated equilibrium. Od razu wypada zaznaczyć, że przy całym sceptycyzmie odnośnie do używania pojęć anglojęzycznych właśnie oryginalne brzmienie tego terminu wydaje się najbardziej zasadne. Dzięki temu unikamy wdawania się w spory terminologiczne, a jednocześnie jasno odwołujemy się do koncepcji znanej z prac autorstwa głównie Franka R. Baumgartnera i Bryana D. Jonesa ${ }^{4}$. Pozostając z konieczności na dużym poziomie ogólności, przypomnijmy, że wzmiankowana teoria zakłada funkcjonowanie polityki według określonego, dość szczególnego wzorca. Jest on mianowicie zdeterminowany przez długie okresy stosunkowo niewielkich zmian, korekt, modyfikacji w polityce oraz z rzadka pojawiających się „tąpnięć”. Taka logika ma swoje bardzo dobre odzwierciedlenie w analizie wydatków budżetowych, o czym szerzej w dalszej części tekstu. W tym miejscu odnotujmy jeszcze tylko fakt, że owe momenty przełomowe, chwile przesileń, potencjalnie sprzyjające zajściu zmian, mają być uwarunkowane zwiększonym zainteresowaniem ze strony aktorów politycznych, zaś decydująca rola ma przypadać nie tyle ilości, ile jakości, sile owego zainteresowania 5 .

Aby jednak nasze przedsięwzięcie miało szansę na powodzenie, należy jasno sprecyzować strukturę wywodu.

Co się tyczy budowy tekstu, punktem wyjścia do jakiejkolwiek analizy jest właśnie uściślenie wykorzystanych pojęć. W konsekwencji właśnie tego dotyczy pierwsza część artykułu. Z kolei jego drugi fragment jest próbą zmierzenia się z zagadnieniem implementacji wybranych decyzji administracji Obamy w ramach polityki zagranicznej. Trzecia część jest nieco bardziej rozbudowana i dotyczy relacji głowy państwa z otoczeniem. Są tutaj omówione trzy jego elementy: (1) prezydenccy najbliżsi współpracownicy odpowiedzialni za politykę zagraniczną i politykę bezpieczeństwa zewnętrznego państwa, (2) doradcy - zarówno formalni, jak i nieformalni, oraz (3) wymiar instytucjonalny amerykańskiej polityki, co w naszym wypadku sprowadza się do relacji z Kongresem. Czwarta, ostatnia, część tekstu zawiera element prognostyczny dotyczący polityki zewnętrznej Stanów Zjednoczonych.

\section{UWAGI DEFINICYJNE}

Fenomen kontynuacji i zmiany w polityce - w tym także w polityce zagranicznej - jest jednym z bardziej stymulujących intelektualnie wyzwań stojących przed wieloma badaczami. Konsekwencją takiego stanu rzeczy jest znaczna liczba analiz pojawiających się

Zob. np.: F.R. Baumgartner, B.D. Jones, Agendas and Instability in American Politics, Chicago 2009; Policy Dynamics, eds. F.R. Baumgartner, B.D. Jones, Chicago 2002; B.D. Jones, T. Sulkin, H.A. Larsen, Policy Punctuations in American Political Institutions, „American Political Science Review” 2003, Vol. 97, nr 1, s. 151-169.

5 Za: B. Szklarski, Przywództwo polityczne między rządzeniem a reprezentacja, [w:] Amerykańska demokracja $w$ XXI wieku, red. A. Mania, P. Laidler, Kraków 2006, s. 154. 
w tym nurcie ${ }^{6}$. Tym bardziej zatem stosowne rozważania wypada zacząć od zdefiniowania kluczowych pojęć.

Oczywiście podstawowym terminem będzie kontynuacja/zmiana w polityce zagranicznej. W najbardziej ogólnym planie zmiana oznacza zaistnienie różnicy pomiędzy dwoma stanami polityki (zagranicznej). Uściślając, analiza zmian oznacza konieczność odniesienia się do trzech aspektów rzeczywistości politycznej; są to: (1) geneza zmian (tutaj zakładamy, że jest to nowa administracja), (2) ich kontekst, punkt odniesienia (dotychczasowa polityka USA wobec wybranych problemów) oraz (3) zestaw możliwych do wykorzystania środków, rozwiązań (np. wola działania i posiadane zasoby, w tym także ludzkie). Każdy z tych trzech elementów należy traktować jako warunek konieczny, ale niewystarczający do wprowadzenia modyfikacji polityki.

Zasadnicze tezy zostaną zilustrowane przy pomocy wspomnianych już wydatków budżetowych. Dzięki ich analizie realne może stać się zoperacjonalizowanie interesującej nas kategorii kontynuacji/zmiany. Biorąc pod uwagę politykę zagraniczną i związaną z nią politykę bezpieczeństwa zewnętrznego, szczególnie istotna rola przypada dwóm kategoriom budżetowym: sprawom międzynarodowym (International Affairs) oraz obronności (National Defense). Pierwsza z nich składa się z następujących podkategorii (w celu uniknięcia ewentualnych nieporozumień pozostawiono wersję anglojęzyczną): International development and humanitarian assistance, International security assistance, Conduct of foreign affairs, Foreign information and exchange activities oraz International financial programs. Z kolei drugą tworzą: Department of Defense- Military, Atomic energy defense activities oraz Defense-related activities. W ramach tak zawężonego obszaru przeanalizowanie zmian - tudzież pokuszenie się o prognozy może być zadaniem stosunkowo prostym.

Taki sposób rozumowania wynika z zastosowania przyjętej perspektywy badawczej; przypomnijmy, że jest nią teoria punctuated equilibrium. W wypadku interesujących nas danych budżetowych ma ona swoją - uznaną w nauce - tradycję ${ }^{7}$. Pomimo intere-

Zob. np.: J.N. Rosenau, The Study of Political Adaptation, London-New York 1981; Why Nations Realign. Foreign Policy Restructuring in the Postwar World, ed. K.J. Holsti, London-Boston 1982; K. Goldmann, Change and Stability in Foreign Policy. The Problems and Possibilities of Détente, Princeton 1988; Ch.F. Hermann, Changing Course. When Governments Choose to Redirect Foreign Policy, „International Studies Quarterly” 1990, Vol. 34, nr 1, s. 3-21; W. Carlsnaes, On Analysing the Dynamics of Foreign Policy Change. A Critique and Reconceptualization, "Cooperation and Conflict” 1993, Vol. 28, nr 1, s. 5-30; Foreign Policy Restructuring. The Politics of Continuity and Change in U.S. Foreign Policy, eds. J.A. Rosati, J.D. Hagan, M.W. Sampson, Columbia 1994; D.A. Welch, Painful Choices. A Theory of Foreign Policy Change, Princeton 2005. Analityczny przegląd stanowisk zob. w: J. Gustavsson, How Should We Study Foreign Policy Change?, „Cooperation and Conflict” 1999, Vol. 34, nr 1, s. 73-95. W literaturze polskojęzycznej zob. np.: Z.J. Pietraś, Koncepcje adaptacji politycznej, [w:] Mechanizmy adaptacji politycznej państwa, red. Z.J. Pietraś, A. Dumała, Lublin 1990, s. 123-158; T. Łoś-Nowak, Polityka zagraniczna - state i zmienne komponenty procesu formutowania i realizacji, [w:] Polityka zagraniczna. Aktorzy, potencjaty, strategie, red. nauk. taż, Warszawa 2011, s. $42-58$.

Zob. np.: A.B. Wildavsky, The Politics of the Budgetary Process, Boston 1964; P. John, H. Margetts, Policy Punctuations in the UK. Fluctuations and Equilibria in Central Government Expenditure since 1951, „Public Administration” 2003, Vol. 81, nr 3, s. 411-413; a zwłaszcza B.D. Jones, F.R. Baumgartner, 
sujących wyników są to jednak analizy traktujące wydatki raczej całościowo, czyli bez wydzielenia polityki zagranicznej.

\section{ANALIZA IMPLEMENTACJI WYBRANYCH DECYZJI W RAMACH POLITYKI ZAGRANICZNEJ BARACKA OBAMY}

Skrótowy przegląd wybranych obszarów obejmuje następujące elementy: (1) Afganistan/Irak, (2) Bliski Wschód, (3) „arabska wiosna”, (4) zbrojenia, broń nuklearna i przeciwdziałanie jej rozpowszechnianiu (tutaj także tarcza antyrakietowa), (5) Daleki Wschód (Chiny), (6) Kanada, (7) Ameryka Łacińska oraz (8) Afryka subsaharyjska ${ }^{8}$. Naturalnie taka selekcja zagadnień zawsze może budzić kontrowersje, jednak wydaje się, że jest ona reprezentatywna, biorąc pod uwagę wydarzenia ostatnich czterech lat amerykańskiej dyplomacji?.

Afganistan/Irak. Nowo wybrany prezydent tradycyjnie, zgodnie z wymogami XX poprawki do Konstytucji USA, obejmuje urząd 20 stycznia. Jedna z pierwszych zapowiedzi Baracka Obamy została wyrażona już 27 lutego 2009 r., a zatem nieco po ponad miesiącu urzędowania. Co istotne, przemówienie dotyczyło zakończenia wojny w Iraku. Mówiąc bardziej szczegółowo, padła tam zapowiedź powrotu „frontowych” żołnierzy amerykańskich do końca sierpnia $2010 \mathrm{r}$. oraz pozostawienia kontyngentu około 35-50 tys. żołnierzy do realizowania zadań szkoleniowych i doradczych. Data całkowitego wycofania sił zbrojnych US Army została wyznaczona na koniec $2011 \mathrm{r}^{10}$ Stosowne terminy zostały dotrzymane. Godzi się w tym miejscu przypomnieć, że było to zgodne z postanowieniami porozumienia zawartego przez prezydenta George'a W. Busha i irackiego premiera Nouriego al-Malikiego jeszcze pod koniec $2008 \mathrm{r}$.

W sferze dyplomatycznej prezydent wskazał przede wszystkim na osobę nowego ambasadora USA w Iraku - Christophera Hilla ${ }^{11}$. Jego przygotowanie, które zdo-

J.L. True, Policy Punctuations. U.S. Budget Authority, 1947-1995, „Journal of Politics” 1998, Vol. 60, nr 1, s. 1-33.

8 Taki wybór był w znacznym stopniu odzwierciedlony na wiosnę 2012 r. w oficjalnej wersji Białego Domu. Por.: [online] http://www.whitehouse.gov/issues/foreign-policy, 3 IV 2012.

9 Jedno z bez wątpienia kluczowych zagadnień, których brak na powyższej liście - kryzys gospodarczy i jego międzynarodowe reperkusje - jest w istocie zjawiskiem, które przejawia się - w różnych aspektach - w relacjach USA z szeregiem uczestników sceny międzynarodowej. Stąd kontekst gospodarczy nie został wyodrębniony jako osobny blok tematyczny, lecz został omówiony przy okazji analizy polityki w stosunku do konkretnych partnerów. Z podobnych względów zrezygnowano z omówienia relacji pomiędzy USA a UE - wielość powiązań skazuje nas w istocie na osobne - i to obszerne - omówienie, które powinno zawierać zarówno stosunki z instytucjami wspólnotowymi, jak i poszczególnymi państwami.

10 Za: [online] http://www.whitehouse.gov/the_press_office/Remarks-of-President-Barack-Obama-Responsibly-Ending-the-War-in-Iraq, 3 IV 2012. W momencie obejmowania urzędu przez Baracka Obamę amerykańskie siły zbrojne w Iraku liczyły około 180 tys. ludzi.

11 Sprawował on także urząd ambasadora USA w Polsce w latach 2000-2004. 
był podczas wcześniejszej służby głównie na Bałkanach (negocjator porozumienia w Dayton, specjalny wysłannik w Kosowie i ambasador USA w Macedonii) oraz jako ambasador USA w Korei Południowej miało być gwarantem powodzenia misji w Iraku. W szczególności miało to polegać na zaktywizowaniu wysiłków na rzecz pozyskania samych Irakijczyków do sprawy odbudowy kraju po zniszczeniach wojennych. Biorąc pod uwagę obecną sytuację w Iraku, stosowne działania można określić w najlepszym razie jako umiarkowane, zaś sam Hill przestał sprawować swój urząd w Bagdadzie już w $2010 \mathrm{r}$.

1 grudnia 2009 r., podczas przemówienia w West Point, prezydent zadeklarował podstawy strategii dla Afganistanu oraz - co charakterystyczne - dla Pakistanu. Wymowne jest odniesienie się do tych dwóch państw w ramach jednego celu politycznego: ograniczenia działalności Al-Kaidy na tym terenie ${ }^{12}$. Osłabienie jej siły rażenia miało się dokonać za pośrednictwem: fizycznej likwidacji bojowników, ograniczania poparcia dla talibów wśród społeczności lokalnych oraz wzmocnienia miejscowych sił bezpieczeństwa. Dodatkowo ustalono harmonogram wycofywania żołnierzy amerykańskich z Afganistanu (13 lipca 2011 r. rozpoczęto wycofywanie pierwszych 650 żołnierzy $)^{13}$. Od razu warto zaznaczyć, że w przemówieniu z 22 czerwca tego roku Barack Obama poinformował o przeszkoleniu ponad 100 tys. funkcjonariuszy afgańskich sił zbrojnych oraz o perspektywie wycofania 10 tys. żołnierzy amerykańskich do końca 2011 r., zaś w całości - do końca 2014 r. ${ }^{14}$ Deklaracje te są o tyle istotne, że w czasie urzędowania Obamy liczba żołnierzy wzrosła z około 33 tys. w styczniu 2009 r. do okoto 90 tys. w 2012 r. $^{15}$

O ile powyższe fakty są istotne, o tyle nikną w cieniu wydarzenia, które zelektryzowało na wiosnę 2011 r. światową opinię publiczną. Otóż, po wielu latach zabiegów, 1 maja tego roku jednostka sił specjalnych USA zabiła Osamę bin Ladena. Prezydent poinformował o tym w wystąpieniu do narodu przed północą tego samego dnia, co spowodowało wybuch euforii na ulicach niektórych amerykańskich miast.

W rocznicę tego wydarzenia - 2 maja 2012 r. - prezydent Barack Obama i prezydent Afganistanu Hamid Karzai podpisali w Kabulu porozumienie o „strategicznym partnerstwie" (taka fraza pojawia się w jego tytule). Co istotne, umowa nie dotyczy kwestii związanych z amerykańską obecnością wojskową w Afganistanie, lecz reguluje sprawy wzajemnej współpracy ekonomicznej, społecznej czy też w sferze edukacji. Bezpośrednim następstwem omawianego aktu prawnego było przyznanie

12 W tym kontekście szczególnie interesująco przedstawia się sytuacja Pakistanu, czyli kraju uznawanego za sojusznika USA w regionie. Jakkolwiek - biorąc pod uwagę sytuację w samym Pakistanie - jest to stwierdzenie dość kontrowersyjne, to warto zwrócić uwagę, że właśnie ambasada tego kraju reprezentuje w USA interesy Iranu. Co więcej, w 2004 r. prezydent George W. Bush określił Pakistan jako jednego z gtównych sojuszników spoza NATO.

13 Za: [online] http://www.whitehouse.gov/the-press-office/remarks-president-address-nation-way-forward-afghanistan-and-pakistan, 3 IV 2012.

14 Zob.: [online] http://www.whitehouse.gov/the-press-office/2011/06/22/remarks-president-way-forward-afghanistan, 3 IV 2012.

$15 \mathrm{Za}$ : [online] http://www.isaf.nato.int/troop-numbers-and-contributions/index.php, 12 XI 2012. 
Afganistanowi statusu jednego z gtównych sojuszników spoza $N A T O^{16}$. Istotnym wydarzeniem był także szczyt NATO w Chicago 21 maja 2012 r., podczas którego zadeklarowano, że Afgańczycy przejmą na siebie ciężar walk do połowy 2013 r., wojska koalicji stopniowo będą się skupiać głównie na działaniach szkoleniowych, zaś ostateczne wycofanie ma nastąicić do końca 2014 r. ${ }^{17}$

Bliski Wschód. Przejdźmy teraz do sprawy bliskiej Afganistanowi i Irakowi zarówno z politycznego, jak i geograficznego punktu widzenia - chodzi o proces pokojowy na Bliskim Wschodzie. Od razu należy zaznaczyć, że stanowisko administracji Baracka Obamy raczej trudno byłoby określić w tej kwestii nowatorskim: wciąż bowiem obowiązuje zasada „dwa narody - dwa państwa”. Tak nakreślony cel ma być realizowany głównie w ramach kontynuowania zaangażowania w bezpieczeństwo państwa Izrael ${ }^{18}$ oraz nakłanianie stron konfliktu do bezpośrednich rozmów ${ }^{19}$. Z drugiej jednak strony godzi się odnotować, że taka - oficjalna - wersja zdarzeń ma także swoje bardziej złożone oblicze. Otóż proces pokojowy został znacznie skomplikowany - zapewne nieświadomie - przez samego prezydenta Obamę. Chcąc bowiem osiągnąć wyjście z impasu, zaproponował on zaprzestanie rozwijania osadnictwa żydowskiego na terenach okupowanych. Miał to być gest dobrej woli w stosunku do społeczności palestyńskiej (i szerzej - muzułmańskiej), zaś w rewanżu Izraelczycy mieli mieć gwarancję kontynuowania rozmów pokojowych. Efekt okazał się przeciwny: propozycja doprowadziła do ochłodzenia w stosunkach amerykańsko-izraelskich, zaś sam palestyński prezydent Mahmoud Abbas stał się zakładnikiem amerykańskich intencji: ponieważ nie mógł bowiem zaproponować czegoś więcej swoim rodakom, został postawiony w sytuacji bez wyjścia, co doprowadziło do napięć wśród Palestyńczyków. Efektem była utrata poparcia dla inicjatywy USA za strony zarówno Izraela, jak i Palestyny ${ }^{20}$.

„Arabska wiosna”. Nieco rozszerzając perspektywę geopolityczną, przyjrzyjmy się reakcjom administracji na wydarzenia w ramach tzw. „arabskiej wiosny”21. W sfe-

16 S. McCrummen, Clinton, in Kabul, Declares Afghanistan a Major U.S. Ally, „The Washington Post” 2012, 7 VII, [online] http://www.washingtonpost.com/world/asia_pacific/clinton-in-kabul-declares-afghanistan-a-major-us-ally/2012/07/07/gJQAj3VDTW_story.html, 8 IX 2012.

17 S. Wilson, K. DeYoung, NATO Leaders Agree on Framework to Wind Down Afghan Mission, „The Washington Post" 2012, 21 V, [on-line:] http://www.washingtonpost.com/world/national-security/ obama-other-nato-leaders-begin-crucial-summit-on-afghanistan/2012/05/21/gIQArWJYfU_story. html, 8 IX 2012.

18 Zob. choćby wielokrotnie przerywane brawami przemówienie prezydenta w czasie kongresu AIPAC (American Israeli Public Affairs Committee) z 22 maja 2011 r.: http://www.whitehouse.gov/the-press-office/2011/05/22/remarks-president-aipac-policy-conference-2011, 8 IX 2012.

19 Np. przemówienie Baracka Obamy przed Zgromadzeniem Ogólnym ONZ z dnia 21 września 2011 r.: [online] http://www.whitehouse.gov/the-press-office/2011/09/21/remarks-president-obama-address-united-nations-general-assembly, 3 IV 2012.

20 Za: M. Indyk, K. Lieberthal, M.E. O’Hanlon, Scoring Obama’s Foreign Policy...

${ }^{21} \quad \mathrm{Z}$ wydarzeń wcześniejszych w stosunku do omawianych poniżej z pewnością na uwagę zasługuje głośne przemówienie prezydenta do świata muzułmańskiego wygłoszone 4 czerwca 2009 r. w Kairze i za- 
rze deklaratywnej USA poparły przemiany w krajach regionu. Jednocześnie świat z zainteresowaniem przyglądał się - zdaniem sympatyków administracji: bardzo ostrożnej, zaś zdaniem krytyków: zbyt bojaźliwej - reakcji na wydarzenia w Libii na wiosnę 2011 r. Faktem jest, że polityka administracji amerykańskiej była dość niezdecydowana: z jednej bowiem strony optowano za przyjęciem stosownej rezolucji Rady Bezpieczeństwa ONZ, która to rezolucja zakładała „tylko” udzielenie pomocy powstańcom, a jednocześnie wielokrotnie deklarowano poparcie dla idei usunięcia Muammara al-Kaddafiego. Dało to asumpt - głównie Chinom i Rosji do kwestionowania intencji Zachodu wobec koncepcji rozwiązania konfliktu libijskiego. Niemniej jednak, patrząc szerzej na reakcję administracji USA na wydarzenia „arabskiej wiosny”, można zaobserwować ciekawą próbę wyważenia pomiędzy amerykańskimi wartościami a strategicznymi interesami USA w tym kluczowym regionie ${ }^{22}$. Problem Bliskiego Wschodu oraz Afryki Północnej został łącznie potraktowany w przemówieniu prezydenta 19 maja 2011 r. (podtrzymano tam dotychczasowe deklaracje ${ }^{23}$. Bolesnym podsumowaniem polityki z czasów pierwszej kadencji Baracka Obamy wobec regionu był atak dokonany 11 września 2012 r. na amerykańską misję dyplomatyczną w Bengazi. W wyniku incydentu zabity został ambasador USA John Christopher Stevens oraz trzech innych amerykańskich dyplomatów.

Zbrojenia, broń nuklearna i przeciwdziałanie jej rozpowszechnianiu. Nie mniej interesująca jest polityka demokratycznej administracji odnośnie do broni masowego rażenia. Przegląd tego zagadnienia rozpocznijmy od szeroko komentowanego wystąpienia w Pradze z 5 kwietnia 2009 r. W przemówieniu tym prezydent zapowiedział: (1) konieczność redukcji arsenałów nuklearnych (wprost wymieniono USA i Rosję), (2) konieczność kontroli w zakresie uniemożliwienia dostępu do broni atomowej innym państwom, (3) zaktywizowanie działań na rzecz przeciwdziałania terroryzmowi międzynarodowemu oraz (4) promowanie aktywności w kierunku zapewnienia pokojowego wykorzystania energii nuklearnej ${ }^{24}$. Biorąc pod uwagę późniejsze wydarzenia, swego rodzaju ciekawostką jest deklaracja poparcia dla budowy tarczy antyrakietowej w Czechach i w Polsce tak dtugo, jak tylko będzie istniato

powiadające „nowe otwarcie” w stosunkach amerykańsko-arabskich. Zob.: [online] http://www.whitehouse.gov/the-press-office/remarks-president-cairo-university-6 IV 09, 8 IX 2012.

Za: M. Indyk, K. Lieberthal, M.E. O’Hanlon, Scoring Obama’s Foreign Policy...

Zob.: [online] http://www.whitehouse.gov/the-press-office/2011/05/19/remarks-president-middle-east-and-north-africa, 8 IX 2012.

24 Zob.: [online] http://www.whitehouse.gov/the_press_office/Remarks-By-President-Barack-Obama-In-Prague-As-Delivered, 14 V 2012. Co szczególnie interesujące, dążenie do redukcji potencjałów nuklearnych stało się jednym z argumentów na rzecz przyznania prezydentowi Obamie Pokojowej Nagrody Nobla w 2009 r. Efektem praktycznym praskiej deklaracji stało się ponowienie - tak dobrze znanej z czasów zimnej wojny - idei spotkań na szczycie. Pierwsze z nich odbyło się w kwietniu $2010 \mathrm{r}$. Kwestia ograniczenia proliferacji broni jądrowej może być w ogóle traktowana jako działanie o charakterze ciągłości priorytetów, lecz jednocześnie - zmiany środków (vide PSI, czyli tzw. Inicjatywa Krakowska z czasów urzędowania George’a Busha Jr.). 
zagrożenie ze strony Iranu (As long as the threat from Iran persists) ${ }^{25}$. Logiczną konsekwencją pierwszej zapowiedzi było podpisanie 8 kwietnia 2010 r., także w Pradze, nowego porozumienia START z Rosją. 22 grudnia tego samego roku zgody na zawarcie zobowiązań udzielił Senat USA, zaś Barack Obama dokonał ratyfikacji 2 lutego $2011 \mathrm{r}$.

Mniej optymistyczny wydźwięk mają wciąż kontynuowane programy nuklearne Iranu i Korei Północnej. Gwoli ilustracji polityki ówczesnej administracji wobec aspiracji atomowych tego pierwszego państwa, warto zaznaczyć, że w tym względzie USA udało się zyskać strategicznych sojuszników w postaci Chin i Rosji - oba państwa poparły bowiem wspomnianą rezolucję Rady Bezpieczeństwa ONZ z 9 czerwca 2010 r. wobec Iranu ${ }^{26}$. Generalnie rzecz ujmując, stanowisko obecnej administracji wobec broni atomowej jest nakierowane na traktowanie jej raczej jako potencjalnego zagrożenia dla pokoju na świecie niż jako jeden z realnych instrumentów w ramach polityki zagranicznej ${ }^{27}$. Potwierdzeniem takiej tezy może być choćby Nuclear Posture Review, czyli tworzone pod egidą Departamentu Obrony głównie na użytek Kongresu zestawienie celów i metod działania w sprawie broni masowego rażenia. Pierwszy taki dokument podpisał prezydent Obama 6 kwietnia 2010 r., a zatem w rocznicę wystąpienia w Pradze. Niejako naturalnie - mając na uwadze problem Iranu i Korei Północnej oczekiwania wobec rządu USA były spore. Zapisy zawarte w Nuclear Posture Review z 2010 r. pokazują jednak, jak złożona może być polityka zagraniczna. Otóż, istotnie, prezydent Obama zapowiedział wycofanie się USA z niektórych planów rozwoju potencjału nuklearnego z czasów administracji swojego poprzednika. Co więcej - padła wyraźna deklaracja o wykluczeniu użycia broni atomowej w stosunku do państw, które jej nie posiadają. Ale jednocześnie, taki postulat - niejako w starym stylu - został obwarowany istotnym zastrzeżeniem: obietnica ta nie dotyczyła państw, które nie są stronami Traktatu o zakazie rozprzestrzeniania broni nuklearnej z 1968 r. Przypomnijmy, że do tej grupy należy m.in. Korea Północna. Tradycyjnie taka polityka dla zwolenników administracji jest działaniem „rozważnym” i „pełnym niuansów”, zaś dla krytyków - brakiem konsekwencji i jasnej strategii działania wobec wyzwań współczesnego świata ${ }^{28}$.

Drugim, obok traktatu START, ważnym aspektem polityki bezpieczeństwa obecnej administracji jest osławiony system tzw. „tarczy antyrakietowej”. Jeszcze w sierpniu

25 Tamże.

26 Na temat potencjału nuklearnego Iranu i polityki Stanów Zjednoczonych zob. np.: raport Kennetha Katzmana, Iran. U.S. Concerns and Policy Responses, Congressional Research Service, Washington, DC 2012, 23 III, [on-line:] http://www.fas.org/sgp/crs/mideast/RL32048.pdf, 7 IV 2012.

27 Zob. np.: przemówienie Baracka Obamy z 1 lipca 2010 r. w związku z uchwaleniem przez Kongres USA Comprehensive Iran Sanctions, Accountability, and Divestment Act. Tekst wystąpienia prezydenta $\mathrm{w}$ : [online] http://www.whitehouse.gov/the-press-office/remarks-president-signing-iran-sanctions-act, 8 IX 2012.

28 Zob. oficjalne przemówienie prezydenta: [online] http://www.whitehouse.gov/the-press-office/ statement-president-barack-obama-release-nuclear-posture-review, 8 IX 2012. Z kolei krytyka choćby w: M. Davis, He's No Ronald Reagan, „The Weekly Standard” 2011, 7 XII, [on-line:] http://www. weeklystandard.com/blogs/hes-no-ronald-reagan_611705.html, 20 X 2012. 
2008 r. zostało podpisane odpowiednie porozumienie z Polską, na mocy którego elementy systemu miały być ulokowane w naszym kraju. Dnia 17 września 2009 r. nowa administracja ogłosiła decyzję o zmianie planów, które zostały nakreślone jeszcze przez republikańską administrację ${ }^{29}$. Według oficjalnego stanowiska rządu USA główne powody modyfikacji to:

- uznanie, że zagrożenie ze strony Iranu nie polega już na możliwości wystrzelenia przez ten kraj rakiet międzykontynentalnych, lecz pocisków o średnim i krótkim zasięgu;

- postęp technologiczny; w interesującej nas sprawie dotyczy on głównie nowej wersji pocisków przechwytujących SM-3 oraz technik związanych z namierzaniem rakiet przeciwnika ${ }^{30}$.

Podstawową konsekwencją tych założeń była decyzja o umieszczeniu głównych instalacji w krajach południowej Europy. Inaczej rzecz ujmując, bezcelowe stało się ulokowanie zapowiedzianej - i uzgodnionej z Pragą - instalacji radarowej w Czechach oraz - także uzgodnionego, tym razem z Warszawą - ulokowania w Polsce naziemnych instalacji przechwytujących pociski ${ }^{31}$. W wyniku rozpisanego na cztery etapy (docelowo do około 2020 r. włącznie) znowelizowanego programu zadeklarowano konieczność podjęcia współpracy z sojusznikami z NATO odnośnie do szczegółów tego planu. Istotnym novum w kwestii tarczy antyrakietowej było zwrócenie uwagi na stronę rosyjską z jej własnym programem rakietowym i wyrażenie nadziei odnośnie do możliwości współpracy $w$ szerszej ochronie naszych wspólnych interesów strategicznych $^{32}$.

Fakt ogłoszenia takiej decyzji w tym dniu - przypomnijmy: 17 września - wywołał żywą reakcję w Polsce. Zresztą cały program obrony antyrakietowej jest przykładem bolesnego rozmijania się rozumienia tej samej sytuacji przez różne strony. Otóż, dla Polski - i Czech - miał to być system gwarantujący bezpieczeństwo tych dwóch krajów w ramach struktur NATO, w co wpisywano także ewentualne zagrożenia ze strony Rosji. Tymczasem dla USA był to zawsze program skierowany przeciwko potencjałowi militarnemu takich państw jak na przykład Iran.

Odmienne rozumienie wizji systemu „tarczy antyrakietowej” przez USA i niektóre państwa Europy Środkowo-Wschodniej doprowadziło do ochłodzenia wzajemnych stosunków. W miesiąc po ogłoszeniu wspomnianej decyzji strona amerykańska próbowała ratować sytuację, wysyłając z misją do Polski, Czech i Rumunii wiceprezydenta Josepha Bidena. Efektem rozmów była propozycja zmodyfikowanej wersji programu. Dodatkowo, na początku grudnia 2009 r., Stany Zjednoczone i Polska zawarly umowę SOFA (Status of Forces Agreement), która określa warunki stacjonowania w Polsce

29 Co znamienne, oryginalne założenia dla później realizowanego planu prezydent George W. Bush ogłosił w przemówieniu 1 maja 2001 r., a zatem jeszcze przed atakami Al-Kaidy.

30 Za: [online] http://www.mda.mil/system/paa.html (oficjalna strona Missile Defense Agency, czyli jednostki odpowiedzialnej w Departamencie Obrony za program tarczy antyrakietowej), 8 IX 2012.

31 Ostatecznie w Polsce umiejscowiono tylko jedną baterię rakiet patriot.

32 Cyt. za: The Phased Adaptive Approach for Missile Defense in Europe Fact Sheet, [online] http://www. mda.mil/system/paa.html, 28 VI 2012. 
amerykańskich żołnierzy i amerykańskiego sprzętu wojskowego. Jednym z efektów tego porozumienia było podpisanie 13 czerwca 2011 r. memorandum w sprawie obecności Sił Powietrznych USA w Polsce ${ }^{33}$.

Daleki Wschód (Chiny). W amerykańskiej polityce zagranicznej w latach 2009-2012 szczególna rola przypadła Azji Wschodniej, co przede wszystkim sprowadza się do relacji z Chinami. Znaczenie rejonu Pacyfiku jest potwierdzone w Strategic Defense Guidance ze stycznia 2012 r. Uderzający jest w tym dokumencie nacisk położony na Azję Wschodnią: rejon Atlantyku nie pojawia się tam ani raz, zaś rejon Pacyfiku - kilkukrotnie. Jeśli natomiast chodzi o nieco precyzyjniejszą analizę, to w amerykańskiej polityce wobec Chin dominują dwa nurty. Z jednej strony Barack Obama stara się „rozmiękczać" chińskie przywództwo poprzez wskazywanie na konieczność prowadzenie dialogu. Takie stanowisko było szczególnie widoczne choćby w czasie wizyty członka Biura Politycznego Chińskiej Partii Komunistycznej Xi Jinpinga w USA w połowie lutego 2012 r. czy też wiceministra spraw zagranicznych ChRL w USA pod koniec października tego samego roku ${ }^{34}$. Od strony formalnej taki kierunek polityki został poprzedzony powołaniem jeszcze w kwietniu 2009 r. sekretarz stanu Hillary Clinton oraz sekretarza skarbu Timothy'ego Geithnera na przedstawicieli USA w amerykańsko-chińskim dialogu strategicznym i ekonomicznym (U.S.-China Strategic and Economic Dialogue).

Jednocześnie, i to jest drugi rys polityki wobec Chin, rosnące znaczenie Państwa Środka w nieunikniony sposób powoduje konieczność odniesienia się do stosownej aktywności międzynarodowej tego kraju. W tej kwestii bodaj najgłośniejsze było spięcie, do którego doszło podczas szczytu państw ASEAN w lipcu 2010 r. Kiedy przedstawiciel Chin twardo przedstawiał argumenty Pekinu, sekretarz stanu Hillary Clinton równie zdecydowanie nazwała rozwiązanie sporów wokół Morza Południowochińskiego gtównym priorytetem oraz opowiedziała się za prowadzeniem polityki wolnego handlu w regionie i konieczności dbania o interesy USA ${ }^{35}$. Przedłużeniem takiego stanowiska była deklaracja Baracka Obamy złożona w trakcie wizyty w Azji Południowo-Wschodniej i w Australii w listopadzie 2011 r. Prezydent USA przekonywał o konieczności powołania regionalnej strefy wolnego handlu, ale bez udziału w niej Chin. Stosowne porozumienie tworzące tzw. Partnerstwo Transpacyficzne (Trans-Pacific Partnership, TPP) podpisały 12 listopada tego roku USA oraz Australia, Brunei, Chile, Malezja,

33 Na mocy tego porozumienia 9 listopada 2012 r. w 32 Bazie Lotnictwa Taktycznego w Łasku zainaugurował działalność pierwszy stacjonujący na stałe w Polsce pododdział amerykańskich sił zbrojnych Aviation Detachment. Pododdział ten składać się ma docelowo maksymalnie z 250 żołnierzy, eskadry myśliwców F-16 i ewentualnie samolotów Hercules.

34 Zob. oficjalna informacja Departamentu Stanu: [online] http://www.state.gov/r/pa/prs/ps/2012/ 10/199611.htm, 13 XI 2012.

35 Za: [online] http://www.bloomberg.com/news/2010-07-23/u-s-says-settling-south-china-sea-disputes-leading-diplomatic-priority-.html, 13 XI 2012. Poza oczywistymi interesami strategicznymi Amerykanie mają tam także istotne interesy ekonomiczne - gwoli przykładu można wspomnieć choćby o odwiertach Exxon Mobil Corporation u wybrzeży Wietnamu. 
Nowa Zelandia, Peru, Singapur i Wietnam. W chwili pisania niniejszego tekstu trwały rozmowy uszczegółowiające ten projekt ${ }^{36}$. Dodatkowo, napięcie na linii WaszyngtonPekin zostało spotęgowane, kiedy Chiny - zresztą przy współudziale Rosji - zablokowały w lutym 2012 r. uchwalenie przez Radę Bezpieczeństwa ONZ rezolucji mającej potępiać syryjskiego prezydenta Bashara al-Assada oraz wzywającej go do ustąpienia.

Ów pesymistyczny obraz stosunków amerykańsko-chińskich jest także wzmocniony sprawą bodaj najpowszechniej komentowaną zarówno przez polityków, jak i obserwatorów sceny międzynarodowej - są to mianowicie stosunki handlowe. Od razu należy zaznaczyć, że interesująco przedstawia się w tym kontekście nasze podstawowe pytanie dotyczące kontynuacji i zmiany w polityce. Otóż od wielu już lat mamy do czynienia ze stałą tendencją, która odznacza się niekorzystnym bilansem handlowym USA z Chinami. Jednocześnie, ów ujemny bilans sukcesywnie się powiększa. Jakkolwiek już sam ten fakt jest powodem troski ze strony Waszyngtonu, to dodatkowo ma to swoje zasadnicze konsekwencje w postaci zbliżania się Chin do miejsca numer 1 wśród partnerów handlowych USA, a tym samym do usunięcia z tego miejsca tradycyjnego lidera, czyli Kanady ${ }^{37}$.

Reasumując, można zauważyć, że wobec wyzwań ekonomicznych (wymiana handlowa, polityka finansowa), strategicznych (roszczenia terytorialne na Morzu Południowochińskim), prawnych (ochrona własności intelektualnej) oraz społecznych (prawa człowieka) - polityka USA wobec Chin nabiera coraz bardziej istotnego znaczenia. Symbolicznym tego potwierdzeniem jest fakt, że po wygranych wyborach prezydenckich sekretarz stanu udała się z pierwszą wizytą zagraniczną do Australii, Singapuru, Tajlandii, Birmy i Kambodży (11-20 listopada 2012 r.).

Kanada. Przegląd „najbliższego sąsiedztwa” USA rozpocznijmy od Kanady. Oczywiście, nie kwestionując przyjętej terminologii („specjalne relacje” są wszakże tradycyjnie zagwarantowane dla stosunków z Wielką Brytanią), warto zauważyć, że i polityka amerykańsko-kanadyjska nie jest pozbawiona szczególnych cech. Pomijając ogólnie znane - i jakże istotne - fakty (NATO, NAFTA, G8, G20, system NORAD etc.) oraz wspomniany już wymiar gospodarczy, przypomnijmy, że to właśnie Kanada jest największym zagranicznym dostawcą energii dla USA ${ }^{38}$. Fakt ten ma swoje konkretne przełożenia na realizację projektu ropociągu Keystone, o czym jest mowa w dalszej części tekstu.

36 Tematykę związaną z wymianą handlową z zagranicą należy uzupełnić o podpisane 21 października 2011 r. porozumienia z Koreą Południową, Kolumbią oraz Panamą.

37 Według oficjalnych danych w listopadzie 2012 r. udział Kanady w amerykańskiej wymianie handlowej stanowił nieco ponad 16\% całości, Chin - 14\%, zaś Meksyku - 13\%. Z kolei deficyt wymiany z Chinami wyniósł w 2012 r. ponad 315 mld dolarów [sic!], z Meksykiem - ponad 61 mld dolarów, zaś z Kanadą - niemal 32 mld dolarów. Dane za: [online] http://www.census.gov/foreign-trade/statistics/highlights/top/top1211yr.html oraz [online] http://www.census.gov/foreign-trade/balance /\#C, 22 XI 2012.

38 Pewną ciekawostką może być fakt, że granicę między USA a Kanadą przekracza dziennie około 300-400 tys. [sic!] obywateli tych krajów. 
Spośród najistotniejszych spraw o charakterze bilateralnym warto wspomnieć o wspólnym działaniu na rzecz eksploracji dna obszaru arktycznego. Istniejące tam złoża surowców mogą stać się dla zainteresowanych istotnym czynnikiem wzmacniającym samowystarczalność energetyczną. Owemu celowi służy Extended Continental Shelf Project, który został zainicjowany jeszcze za czasów urzędowania George’a W. Busha i był kontynuowany w czasie pierwszej administracji Baracka Obamy przy współudziale Kanady.

Ameryka Łacińska. Przechodząc na południe od USA, odnotujmy, że Ameryka Łacińska znalazła swoje miejsce w deklaracjach Baracka Obamy głównie odnośnie do konieczności współpracy w ramach zachodniej hemisfery w przeciwdziałaniu wspólnym zagrożeniom. Takie stanowisko rządu amerykańskiego zostało zaprezentowane podczas szczytu państw amerykańskich w Trynidadzie i Tobago oraz podczas wizyt w Brazylii, Chile i Salwadorze. W sprawie o szczególnym znaczeniu - kwestii Kuby prezydent USA ogłosił 13 kwietnia 2009 r. potrzebę kontynuowania nacisków nakierowanych na „rozmiękczanie” reżimu komunistycznego na wyspie. Spośród rozwiązań szczegółowych, nakierowanych na Kubańczyków przebywających zarówno w swej ojczyźnie, jak i w USA, zaproponowano m.in. zlikwidowanie barier w przepływie osób między tymi krajami, zainicjowanie bezpośrednich połączeń telekomunikacyjnych (włącznie w usługą roamingu), włączenie Kuby w obszar objęty zasięgiem nadawania przez amerykańskie radio i TV, rozszerzenie listy towarów dozwolonych do eksportu na wyspę o produkty służące realizowaniu pomocy humanitarnej ${ }^{39}$. Co znamienne, w tej ostatniej kwestii (paczki z darami) podtrzymano obowiązujący od wielu lat zakaz ich wysyłki członkom Kubańskiej Partii Komunistycznej i członkom rządu Kuby.

Do znacznego stopnia elementy kontynuacji są widoczne w stosunkach amerykańsko-meksykańskich, przynajmniej w odniesieniu do tak palącej kwestii, jak przestępczość zorganizowana i przemyt narkotyków. Pierwsza administracja Baracka Obamy realizowała bowiem politykę wyznaczoną przez George’a W. Busha i podpisaną przez niego jeszcze w czerwcu 2008 r. ustawą powołującą do życia tzw. inicjatywę Mérida. Program ten jest nie tylko realizowany, ale i rozwijany dzięki finansom uchwalanym przez Kongres USA oraz powołanej - po deklaracji prezydenta z kwietnia 2009 r. - Caribbean Basin Security Initiative (CBSI) ${ }^{40}$.

Afryka subsaharyjska. Kwestią najistotniejszą w ramach polityki wobec Afryki subsaharyjskiej była sytuacja w Sudanie. Po latach wojny domowej, przy poparciu USA, 9 lipca 2011 r. proklamowano powstanie Republiki Sudanu Południowego. Długim cieniem kładzie się jednak obecna sytuacja, czyli ponowny wybuch wojny o podłożu etnicznym oraz surowcowym (złoża ropy naftowej) - tym razem jednak już pomiędzy formalnie niepodległymi krajami.

39 Tekstw: [online] http://www.whitehouse.gov/the_press_office/Fact-Sheet-Reaching-out-to-the-Cuban-people, 22 XI 2012.

40 Na temat CBSI zob. np.: [online] http://www.state.gov/p/wha/rt/cbsi/, 22 XI 2012. 
Przegląd działań na arenie międzynarodowej warto zakończyć dwoma kwestiami z pogranicza polityki zagranicznej i polityki wewnętrznej. Po pierwsze, w czasie kampanii wyborczej w 2008 r. wielokrotnie padała deklaracja o konieczności zamknięcia więzienia w bazie Guantanamo. Póki co mamy jednak do czynienia z dość kuriozalną sytuacją: podejrzani są tam w momencie pisania artykułu (2012 r.) wciąż przetrzymywani, lecz istnienie samego więzienia na oficjalnej stronie Białego Domu (sic!) jest określane jako zagrożenie dla naszego [amerykańskiego] bezpieczeństwa (prison at Guantanamo Bay, which endangers our security $)^{41}$. Jednocześnie powołano grupę zadaniową (Special Task Force), której celem było przeanalizowanie dotychczas prowadzonej polityki w stosunku do zatrzymanych.

Drugim mocno akcentowanym w kampanii wątkiem był postulat zaktywizowania działań na rzecz ochrony środowiska naturalnego. Obok stosownych działań wewnętrznych (postulat przeznaczenia około 150 mld dolarów w ciągu 10 lat na badania i rozwój „zielonej energii” w USA), nie brakło także zapowiedzi działań na arenie międzynarodowej ${ }^{42}$. Jednak póki co sprawa najbardziej katalizująca zainteresowanie - amerykański akces do protokołu z Kioto - wciąż pozostaje nierozstrzygnięta.

Osobnego potraktowania wymaga dokument o dosłownie globalnym zasięgu - chodzi o ogłoszoną 27 maja 2010 r. Strategię Bezpieczeństwa Narodowego. Przedmiotowy tekst dość wiernie wpisuje się w praktykę publikowania co jakiś czas przez niektóre administracje deklaracji zasad odnośnie do najważniejszych wyzwań, przed którymi stoi kraj. Jest to zatem raczej typowy, niż rewolucyjny, w założeniach dokument urzędującej administracjít ${ }^{43}$.

Wracając do zaznaczonej na początku tekstu perspektywy analitycznej - czyli kontynuacji/zmiany - raczej trudno byłoby zaliczyć powyższe działania do nowatorskich, rewolucyjnych, przełomowych ${ }^{44}$. Wyjątkiem od tej reguły mógłby być co najwyżej nomen omen - nowy start w stosunkach z Rosją. Polityka demokratycznej administracji wobec Moskwy układa się - zapewne nie bez powodu - zgodnie z tym, kto jest prezydentem Rosji. W sytuacji, kiedy był nim - uważany za relatywnie otwartego na argumenty Zachodu - Dmitrij Miedwiediew, stosunki USA-Rosja układały się względnie poprawnie. Gwoli przykładu przypomnijmy o układzie START, decy-

41 Zob.: [online] http://www.whitehouse.gov/issues/foreign-policy, 14 V 2012.

42 Chodzi zwłaszcza o udział prezydenta i jego wypowiedzi w czasie „szczytu klimatycznego” w Kopenhadze w grudniu 2009 r.; zob. np. odpowiedzi na pytania dziennikarzy: [online] http:// www.whitehouse.gov/the-press-office/remarks-president-during-press-availability-copenhagen, $14 \mathrm{~V}$ 2012. Co znamienne, odpowiadając na jedno z pytań, Barack Obama przyznał, że podjęte ustalenia mają charakter umowny, a nie spisany.

43 Pełny tekst zob.: [online] http://www.whitehouse.gov/sites/default/files/rss_viewer/national_security_strategy.pdf, 14 V 2012. Jej dopełnieniem są: opublikowana 16 maja 2011 r. Międzynarodowa Strategia na rzecz Cyberprzestrzeni oraz Narodowa Strategia Zwalczania Terroryzmu z 28 czerwca 2011 r.; zob. teksty dokumentów - odpowiednio - w: [online] http://www.whitehouse.gov/sites/ default/files/rss_viewer/internationalstrategy_cyberspace.pdf, $14 \mathrm{~V} 2012$, oraz [online] http://www. whitehouse.gov/sites/default/files/counterterrorism_strategy.pdf, 14 V 2012.

44 Zob. np.: M. Indyk, K. Lieberthal, M.E. O’Hanlon, Scoring Obama’s Foreign Policy... 
zji z listopada 2010 r. o umożliwieniu realizowaniu dostaw NATO do Afganistanu via Rosja, obietnicy prezydenta Baracka Obamy odnośnie do rozpoczęcia prac nad zniesieniem poprawki Jacksona-Vanika w celu uzyskania stanu normalnych stosunków handlowych (Permanent Normal Trade Relations, PNTR) ${ }^{45}$ czy też włączeniu Rosji do WTO, co ostatecznie dokonało się 22 sierpnia 2012 r. Z kolei prezydentura Władimira Putina powoduje dość wstrzemięźliwe reakcje szeregu amerykańskich polityków. Kwestią wtórną jest przy tym powód takiego stanu rzeczy - możemy wskazać zarówno na sprawy wewnętrzne (ostatnie wybory do Dumy i traktowanie opozycji w Rosji), jak i na politykę zagraniczną (choćby rosyjska zapowiedź powołania z Białorusią i Kazachstanem Unii Euroazjatyckiej do... 2013 r. $)^{46}$. Powyższe fakty wskazują, że Rosja była i jest istotnym punktem odniesienia dla działań Stanów Zjednoczonych.

Taka konstatacja - akcentująca jednak ciągłość amerykańskiej polityki zagranicznej - może budzić pewne zdziwienie głównie z jednego powodu. Nie jest nim bynajmniej eksploatowana retoryka zmian(y). Otóż podkreśla się, że polityka zagraniczna Baracka Obamy jest bardziej pragmatyczna niż ideologiczna ${ }^{47}$. Za przykład może służyć choćby następująca wypowiedź sekretarz stanu Hillary Clinton: Musimy wciąż na nich [Chińczyków] naciskać. Lecz nasza presja na te sprawy [prawa człowieka] nie może kolidować z globalnym kryzysem gospodarczym, klimatycznym i sprawami bezpieczeństwa ${ }^{48}$. Dodać do tego można szereg wypowiedzi różnych przedstawicieli administracji - tudzież i samego prezydenta - stawiających wątek dotyczący bezpieczeństwa raczej przed zagadnieniami dotyczącymi na przyklad promowania demokracji. A zatem, jeżeli mówimy o pragmatyzmie tej administracji, to jak to połączyć z tezą o kontynuacji ? Otóż wydaje się, że niezależnie od wskazywanych przesłanek - pragmatyzm i ideowość - celem nadrzędnym, uniwersalnym, niezmiennym w ramach każdej administracji jest wyważenie pomiędzy amerykańskimi interesami a amerykańskimi ideami. Próba zbalansowania tych dwóch wymiarów bywa zazwyczaj karkołomna, co też częściowo uwidacznia powyższy przegląd działań administracji Baracka Obamy, zaś przypadek polityki wobec Chin jest symptomatyczny.

45 Taka deklaracja została złożona w listopadzie 2011 r. w czasie spotkania prezydentów USA i Rosji. Owa poprawka, uchwalona jeszcze w 1974 r., wymierzona była w ówczesne państwa komunistyczne i ich restrykcyjną politykę emigracyjną. Na mocy przedmiotowego uregulowania USA mają możliwość prowadzenia ograniczonej wymiany handlowej z takimi krajami.

46 Omawiany tutaj symboliczny „reset” we wzajemnych stosunkach Waszyngtonu i Moskwy opierał się m.in. na odrzuceniu dotychczasowej polityki amerykańskiej zdominowanej przez USA wypowiedzeniem w grudniu 2001 r. - podpisanego jeszcze w 1972 r. - traktatu ABM.

47 Zob.: M. Indyk, K. Lieberthal, M.E. O’Hanlon, Scoring Obama's Foreign Policy... Por.: H.R. Nau, Obama's Foreign Policy. The Swing Away from Bush. How Far to Go?, „Policy Review” 2010, April/ May, [online] http://www.hoover.org/publications/policy-review/article/5287, 12 VI 2012.

48 Cyt. za: P. Richter, Hillary Clinton to Table Human Rights Issues in China Talks, „Los Angeles Times" 2009, 21 II, [online] http://articles.latimes.com/2009/feb/21/world/fg-clinton-china21, 22 V 2012. 


\section{WYMIAR PERSONALNY POLITYKI ZAGRANICZNEJ BARACKA OBAMY}

Rola współpracowników danego prezydenta w kreowaniu polityki zagranicznej kraju jest zazwyczaj kluczowa. To, kto, kiedy i jak doradza prezydentowi, ma przecież przełożenie na proces decyzyjny w Białym Domu. Ciekawie w tym kontekście może brzmieć opinia, jakoby obecna polityka była bardziej efektem działań samego prezydenta niż jego doradców ${ }^{49}$. Czy jednak taka konstatacja może nas uprawniać do pominięcia tego wymiaru polityki zewnętrznej? Z pewnością nie. Przyjrzyjmy się zatem kluczowym osobom tworzącym otoczenie prezydenta w latach 2009-2012.

$\mathrm{Z}$ punktu widzenia tematyki niniejszego tekstu przegląd personalny obecnej administracji wypada zacząć od osoby sekretarz stanu. Pozostawmy na boku symboliczną wymowę faktu, że mamy do czynienia z trzecią kobietą w historii na tym stanowisku (po Madeleine Albright i Condoleezzie Rice). Znacznie istotniejszy był fakt wskazania właśnie na tę konkretną kandydaturę - Hillary Clinton. Koniecznie trzeba w tym miejscu przypomnieć, że była ona niemal do końca główną rywalką Baracka Obamy do uzyskania nominacji partii demokratycznej w wyborach w $2008 \mathrm{r}^{50}$ Po jej przegranej niektórzy komentatorzy - niejako „naturalnie” - próbowali wskazać na Hillary Clinton jako na kandydatkę na urząd wiceprezydenta USA. Były to jednak chybione spekulacje, co nie powinno wcale dziwić, biorąc pod uwagę z jednej strony symboliczny charakter stanowiska wiceprezydenta, a z drugiej - ambicje polityczne żony poprzedniego prezydenta USA z partii demokratycznej. W istocie bowiem, zastępca głowy państwa amerykańskiego jest jak cztowiek w stanie kataleptycznym: nie może mówić, nie może się poruszyć, nie czuje bólu. Jest w petni świadomy tego, co się dzieje, lecz w niczym nie uczestniczy ${ }^{51}$. Jakkolwiek może się nam to wydawać diagnozą zbyt radykalną, to warto odnotować, że są to słowa jednego $\mathrm{z}$ wiceprezydentów (Thomas R. Marshall w administracji Woodrowa Wilsona) cytowane we wspomnieniach innego wiceprezydenta (w administracji Harry'ego Trumana). W zasadzie jedyną istotną i oficjalnie usankcjonowaną rolą wiceprezydenta jest oczekiwanie na możliwość... objęcia urzędu prezydenta USA. Na tym tle znacznie ciekawsze perspektywy realnego wpływu na politykę wiążą się właśnie ze stanowiskiem sekretarza stanu.

Biorąc pod uwagę powyżej zasygnalizowany kontekst rywalizacji politycznej między Barackiem Obamą a Hillary Clinton, dość zaskakująco może brzmieć informacja, że szefowa Departamentu Stanu została zaprzysiężona, jako 67. sekretarz stanu, już 21 stycznia 2009 r., a zatem - na drugi dzień po objęciu urzędu przez prezydenta. Fakt ten powinien być interpretowany jako podkreślenie znaczenia omawianego urzędu w strukturze administracji federalnej. Przygotowanie polityczne Hillary Clinton jest bezdyskusyjne. Pomijając fakt bycia przez osiem lat „pierwszą damą”, co przecież też

\footnotetext{
49 Za: M. Indyk, K. Lieberthal, M.E. O’Hanlon, Scoring Obama's Foreign Policy...

50 Decyzję o rezygnacji z wyścigu ogłosiła, po zaciętej i wyrównanej walce, 7 czerwca 2008 r.

51 Cyt. za: A.W. Barkley, That Reminds Me, Garden City-Doubleday 1954, s. 221.
} 
ma swoją wymowę, jako senator w czasie dwóch kadencji zasiadała m.in. w komisji ds. służb zbrojnych oraz w komisji budżetowej. Jeżeli chodzi o politykę zagraniczną, to dała się poznać jako orędowniczka prowadzenia polityki opartej na idei smart power. Jakkolwiek sama Clinton nie jest twórcą tego pojęcia, to jej wyraźne wskazanie na tak realizowaną politykę przyczyniło się do spopularyzowania tej koncepcji. W kluczowym fragmencie swoich zeznań przed senacką komisją ds. polityki zagranicznej (w czasie procedury zatwierdzania na stanowisko sekretarza stanu w dniu 13 stycznia 2009 r.) zadeklarowała: Musimy siegać do tego, co zostato nazwane "smart power". Chodzi o szeroki zestaw narzędzi, którymi dysponujemy w sferze dyplomatycznej, ekonomicznej, wojskowej, politycznej, prawnej oraz kulturalnej. Chodzi o wybieranie wtaściwych narzędzi, lub też ich kombinacje, zależnie od zaistniatych okoliczności $i^{52}$. Nieco inną interpretację nadał omawianemu terminowi sam prezydent, który zadeklarował, że ta koncepcja ma być jednym z trzech - obok dyplomacji i siły militarnej - filarów amerykańskiej polityki zagranicznej ${ }^{j 3}$.

Co się zaś tyczy samego wiceprezydenta, to należy podkreślić spore doświadczenie polityczne Josepha Bidena, zwłaszcza w odniesieniu do spraw zewnętrznych. Będąc przez 36 lat senatorem ze stanu Delaware, zasiadał m.in. w komisji ds. polityki zagranicznej, której był przewodniczącym w latach 2007-2009. Pozwala mu to odgrywać dość istotną rolę w otoczeniu prezydenta, co uwidoczniło się choćby w jego zabiegach w momencie senackiej procedury wyrażania zgody na ratyfikację traktatu START. O aktywności wiceprezydenta może też świadczyć lista jego wizyt zagranicznych ${ }^{54}$.

Obok zwierzchnika Departamentu Stanu, drugim kluczowym sekretarzem jest szef Departamentu Obrony. Podobnie jak było w wypadku Hillary Clinton, tak i tutaj prezydenckie decyzje personalne z przełomu lat 2008-2009 wzbudziły emocje. Otóż, argumentując swoje działanie koniecznością zapewnienia ciągłości działań w wojnie w Iraku i Afganistanie, prezydent elekt wskazał na dotychczasowego sekretarza obrony jako na swojego kandydata na przedmiotowe stanowisko. Jest to do dzisiaj jedyny przypadek, kiedy nowo wybrany prezydent pozostawia na tym stanowisku polityka związanego $\mathrm{z}$ administracją poprzednika pochodzącego z drugiej partii politycznej. Tym samym, Robert M. Gates sprawował swój urząd aż przez kolejne dwa i pół roku, do czasu kiedy to 1 lipca 2011 r. zastąpił go Leon E. Panetta. Zarysowujący się w tym momencie obraz ponadpartyjnej polityki zagranicznej wzmacnia także życiorys samego Panetty. Otóż, został on w marcu 2006 r. wybrany na członka Iraq Study Group, monitującej w Kongresie na rzecz przeprowadzenia niezależnej oceny działań w Iraku. Bezpośrednio przed objęciem obecnego urzędu, od lutego 2009 r., Leon Panetta był szefem CIA. Wskazanie przez Baracka Obamę na polityka posiadającego określone doświadczenie polityczne $e^{55}$

Za: [online] http://www.state.gov/secretary/rm/2009a/01/115196.htm, 7 IV 2012.

53 Zob. potwierdzenie choćby we wspomnianym przemówieniu Baracka Obamy z 19 maja 2011 r.

54 Zob.: [online] http://www.whitehouse.gov/administration/vice-president-biden, 7 IV 2012.

55 Poza wskazanymi funkcjami, warto dodać, że Panetta był także szefem doradców prezydenta Billa Clintona, zwierzchnikiem Office of Management and Budget oraz - przez 16 lat - kongresmanem z Kalifornii. 
może być interpretowane jako dążenie do zapewnienia sobie w najbliższym otoczeniu sztabu profesjonalistów, tym bardziej że sam prezydent nie ma żadnego doświadczenia wojskowego.

Spośród pozostałych wyższych urzędników federalnych wchodzących w skład najbliższego otoczenia prezydenta USA warto wspomnieć choćby Janet Napolitano, która od początku urzędowania obecnej administracji stoi na czele Departamentu Bezpieczeństwa Wewnętrznego. Była gubernator Arizony jest stosunkowo wysoko ceniona za swoje kompetencje, wśród których są także te mieszczące się w ramach jej obecnych obowiązków.

Innym ważnym urzędem federalnym jest - w interesującym nas zakresie - zwierzchnik amerykańskich służb wywiadowczych (Director of National Intelligence). Funkcję tę - od początku sierpnia 2010 r. - sprawuje James R. Clapper. Jest to emerytowany wojskowy z wieloletnim doświadczeniem w zakresie działania w strukturach wywiadu USA. Nadaje to pierwszej administracji Baracka Obamy rysu ponadpartyjnego "gabinetu fachowców". Z formalnego punktu widzenia podwładnym zwierzchnika służb wywiadowczych jest dyrektor CIA. Funkcję tę pełnił od września 2011 do 9 listopada 2012 r. generał David H. Petraeus, który wcześniej był dowodzącym siłami sojuszniczymi w Afganistanie i Iraku.

Spoglądając nieco niżej na szczeble biurokracji federalnej, w ramach Departamentu Stanu i podlegającej mu służby dyplomatycznej, należy wskazać na osobę ambasadora USA akredytowanego przy ONZ - Susan Rice. Podobnie jak jej wyżej ulokowani w hierarchii koledzy, tak i ona posiada dość dobre przygotowanie: zasiadała w administracji Billa Clintona w National Security Council (sprawowała tam też funkcje kierownicze), była doradcą ds. Afryki w Departamencie Stanu za czasów drugiej administracji Clintona i współpracowała ze znanym think tankiem (co wymowne - chodzi o raczej konserwatywny Brookings Institution). Istotną rekomendacją było także doradzanie Barackowi Obamie w sprawach polityki zagranicznej w czasie kampanii wyborczej w 2008 r. Bez specjalnych emocji jej kandydatura na obecne stanowisko została pozytywnie i jednogłośnie zaopiniowana przez Senat 22 stycznia 2009 r.

O ile powyższe osoby zazwyczaj działają w ramach sformalizowanych struktur i procedur, o tyle mgłą tajemnicy okryta jest działalność „szarych eminencji” każdej administracji. Zarówno formalni, jak i - zwłaszcza - nieformalni doradcy danego prezydenta tworzą swój własny krąg, własną quasi-strukturę organizacyjną. Ich funkcjonowanie można porównać do elementów układu słonecznego, gdzie w centrum znajduje się oczywiście prezydent, wokół niego krążą planety i gwiazdy (zwierzchnicy sformalizowanych agencji, z sekretarzami departamentów na czele) oraz właśnie pojawiający się na firmamencie i znikający we własnym tempie niczym tajemnicze komety - doradcy. W praktyce politycznej USA są oni włączani w ramy środowiska decyzyjnego - tudzież z niego wyłączani - na mocy osobistej decyzji urzędującego prezydenta. Mówiąc inaczej, ich istnienie w otoczeniu prezydenta nie jest zależne od konstytucyjnie określonego wymogu zatwierdzenia przez Senat. W konsekwencji, prezydenccy doradcy są odpowiedzialni tylko przed prezydentem (oczywiście pomijając standardową odpowie- 
dzialność karną). Co dla nas niesłychanie istotne - wobec braku rozwiązań formalnoprawnych - efekty działania doradców są raczej przedmiotem enuncjacji medialnych i - po latach - twórczości pamiętnikarskiej, niż wynikają z zaobserwowania niepodważalnych faktów.

Spośród grona najistotniejszych formalnych doradców warto wymienić choćby stanowisko zwierzchnika National Security Council (NSC), a tym samym - prezydenckiego doradcy ds. bezpieczeństwa narodowego. Na początku kadencji Baracka Obamy, od 20 stycznia 2009 r. do 8 października 2010 r., sprawował ten urząd generał James L. Jones. Jego kariera to - tyleż typowe, co krytykowane w USA - nieustające przeplatanie się aktywności w strukturach wojskowych i świecie (dużego) biznesu ${ }^{56}$. Przejęcie urzędu zwierzchnika NSC przez jego obecnego szefa - Thomasa E. Donilona - odbyło się dość płynnie, gdyż ten z kolei sprawował wcześniej funkcję zastępcy właśnie Jamesa L. Jonesa i należał do ścisłego grona współpracowników prezydenta ${ }^{57}$. Według nieoficjalnych informacji przekazanych przez media powodem zmiany doradcy ds. bezpieczeństwa narodowego miał być brak należytej współpracy z innymi politykami najwyższego szczebla w otoczeniu Baracka Obamy, w szczególności chodziło o ówczesnego szefa doradców (był nim wpływowy Rahm Emanuel) oraz sekretarza obrony Roberta Gatesa $^{58}$.

Grono nieformalnych doradców otwiera z pewnością właśnie Rahm Emanuel. Ten demokratyczny polityk z Chicago był wcześniej doradcą prezydenta Billa Clintona oraz jednym z najbliższych doradców Obamy w czasie kampanii wyborczej i naturalną koleją rzeczy został szefem administracji prezydenta (White House Chief of Staff). Dzięki zdecydowanemu - i skutecznemu - stylowi działania doczekał się przezwiska „Rahmbo”. Wybór osoby tak zaprawionej w bojach parlamentarnych nie powinien budzić większego zdziwienia, jeśli weźmiemy pod uwagę, że - poza wszystkimi innymi obowiązkami - głównym zadaniem szefa administracji jest właśnie współpraca z Kongresem odnośnie do prezydenckich propozycji legislacyjnych. Jego odejście z Białego Domu w październiku 2010 r. miało być spowodowane - przynajmniej według oficjalnej wersji - ubieganiem się o urząd burmistrza Chicago, co zresztą zakończyło się sukcesem zainteresowanego w lutym $2011 \mathrm{r}$.

Kolejnym politykiem sprawdzonym w administracji Billa Clintona oraz będącym członkiem "chicagowskiej drużyny” jest David M. Axelrod. Został on jednym z trzech głównych doradców (senior advisor) prezydenta Baracka Obamy już 20 stycznia 2009 r. Jako tzw. spin doctor Axelrod był odpowiedzialny za komunikację prezydenta, co obejmowało także m.in. pisanie przemówień. Sprawował swój urząd do początku 2011 r., kiedy został skierowany do prac przygotowawczych nad prezydencką kampanią wyborczą w 2012 r.

56 W tym obszarze był na liście płac takich korporacji, jak m.in. Boeing i Chevron.

57 Jako ciekawostki podajmy, że Thomas E. Donilon do 2005 r. pracował m.in. w Fannie Mae - jednym z niesławnych bohaterów kryzysu finansowego w USA na jesieni 2008 r., zaś jego żona pracuje dla żony wiceprezydenta Josepha Bidena, z kolei brat Donilona jest doradcą wiceprezydenta. 
Kolejną ważną osobą z najbliższego otoczenia prezydenta jest Jacob Lew. Podobnie jak Panetta, także i Lew sprawowal - zresztą dwukrotnie - funkcję szefa Office of Management and Budget, zaś obecnie - od stycznia 2012 r. - jest White House Chief of Staff.

$\mathrm{Z}$ punktu widzenia tematyki niniejszego tekstu nie bez znaczenia jest fakt, że zarówno Emanuel, Axelrod, jak i właśnie Lew są Amerykanami pochodzenia żydowskiego. Co więcej - w wypadku tego ostatniego powszechnie znane jest jego zaangażowanie religijne. W związku z tym, niejako naturalnie, interesy Izraela znajdują swoich sojuszników w najbliższym otoczeniu prezydenta USA. Według niektórych osoba Jacoba Lewa ma także umożliwić Barackowi Obamie polepszenie relacji z premierem Izraela - Benjaminem Netanyahu ${ }^{59}$. Mamy więc echo sytuacji z czasów urzędowania George’a Busha Jr., którego otoczenie także składało się z wielu osób pochodzenia żydowskiego, z tym że funkcjonowali oni w ramach nurtu neokonserwatywnego.

Biorąc pod uwagę powyżej nakreślony schemat personalny, zasadne wydaje się pytanie: jak ów system funkcjonuje w praktyce politycznej? Czy brak tarć pomiędzy elementami tej personalnej układanki? Oczywiście tak nie jest. Konflikty - czy też „różnice zdań” - w ramach prezydenckich administracji zdarzały się zawsze. O niektórych wspomniano powyżej. Dodajmy do tego jeszcze głośną sprawę z połowy 2010 r. Wówczas to pełniący dowódcze stanowisko w Iraku generał Stanley McChrystal skrytykował w wywiadzie udzielonym magazynowi „Rolling Stone” niektórych członków prezydenckiego otoczenia ${ }^{60}$. Reakcja samego Baracka Obamy była daleka od powściągliwości - niemal natychmiast generał został odwołany ze stanowiska i zastąpiony przez generała Davida Petraeusa.

Tematykę związaną z wymiarem personalnym polityki administracji Baracka Obamy zamykają zagadnienia z poziomu instytucjonalnego (współpraca z Kongresem). Od razu wspomnijmy, że mówimy o dwóch kadencjach Kongresu - 111 . (2009-2010) oraz 112. (2011-2012) ${ }^{61}$. Owo rozróżnienie jest o tyle istotne, że w wyniku wyborów kongresowych w 2010 r. w Senacie republikanie zyskali pięć dodatkowych mandatów, co daje im w sumie 47 miejsc. Spośród ważnych dla omawianego tematu komisji najistotniejsza rola przypada zdecydowanie komisji ds. stosunków zewnętrznych (Foreign Relations Committee). Zgodnie z przyjętymi rozwiązaniami jej przewodniczenie przypada partii większościowej i w 112. kadencji funkcję tę sprawował znany senator John Kerry. Z kolei komisji ds. wojskowych (Armed Services

59 D. Gibson, New White House Staffers, Cecilia Munoz And Jacob Lew, Have Strategic Catholic, Jewish Ties, [online] http://www.huffingtonpost.com/2012/01/10/white-house-cecilia-munoz-jacob-lew_ n_1197664.html, 20 X 2012.

60 Zob.: [online] http://www.rollingstone.com/politics/news/the-runaway-general-20100622, $20 \mathrm{X}$ 2012.

${ }^{61}$ Dość często jest także stosowany w USA sposób zapisu lat kadencji Kongresu w wersji obejmującej trzy lata, co może być nieco mylące wobec faktu, że w istocie mamy do czynienia z dwuletnią kadencją. Wyjaśnienie takiego stanu rzeczy jest dość banalne - za daty graniczne w takim zapisie przyjmuje się kalendarzowe lata rozpoczęcia i zakończenia kadencji Kongresu, co mogłoby wskazywać jakoby na trzyletni okres. W rzeczywistości są to pełne dwa lata pomiędzy - np. w wypadku 111. kadencji 3 stycznia 2009 r. a 3 stycznia 2011 r. 
Committee) przewodniczył demokratyczny senator Carl Levin (jego zastępcą z ramienia partii republikańskiej był John McCain, czyli kandydat republikanów na prezydenta w 2008 r.).

Z kolei w Izbie Reprezentantów 112. kadencji republikanie mieli 242 kongresmanów, czyli udało się im zagwarantować większość bezwzględną 50\%. W konsekwencji, to republikanie stanowili większość członków komisji ds. wojskowych (Armed Services Committee), której przewodniczącym był przedstawiciel tejże partii politycznej (Howard P. McKeon z Kalifornii). Druga interesująca nas komisja - ds. polityki zagranicznej (Foreign Affairs Committee) - była kierowana przez republikańskiego polityka z Florydy (co istotne, jest to urodzona na Kubie Ileana Ros-Lehtinen).

Taki stan rzeczy w naturalny sposób musiał przekładać się na współpracę z Kapitolem. Generalnie rzecz ujmując, była ona w porównaniu ze 111. kadencją znacznie bardziej utrudniona. Wyrazem tego może być choćby dość napięta sytuacja w senackiej komisji ds. stosunków zewnętrznych. Przypomnijmy, że była ona kierowana przez prominentnego demokratę (John Kerry), który zastąpił na tym stanowisku obecnego wiceprezydenta. Powinno to zatem stanowić naturalne zaplecze polityczne dla administracji. Tymczasem mieliśmy do czynienia z silną, aktywną i zdecydowanie działającą opozycją. Przykładem takiej aktywności może być na przykład kwestia dość szczególnie lokująca się w ramach polityki zagranicznej - chodzi bowiem o budowany ropociąg Keystone z prowincji Alberta w Kanadzie do kilku miejsc w USA, niektórych tak odległych jak choćby Teksas. Ze względu na opór ze strony prezydenckiej administracji projekt przebiega dość ślamazarnie, a decyzje o kontynuowaniu niektórych jego odcinków zostały odłożone do 2013 r. na mocy decyzji prezydenta (chodzi m.in. o protesty ekologów). Sprawa ta jest przedmiotem walki w Senacie, gdzie gorącym orędownikiem budowy był na przykład republikański senator Richard Lugar, sprawujący do 2012 r. funkcję zastępcy Johna Kerry'ego w komisji ds. stosunków zewnętrznych.

Jak łatwo się domyślić, ze względu na podział miejsc między demokratów i republikanów sytuacja w Izbie Reprezentantów 112. kadencji była jeszcze bardziej napięta. Miało to także swoje odzwierciedlenie w interesującym nas obszarze kompetencji izby niższej, czyli wpływie na kształt budżetu. Na tym tle dochodziło czasami do konfliktów pomiędzy przedstawicielami obu partii politycznych, gdyż republikanie dążyli do zapewnienia wydatków na obronność na odpowiednio wysokim poziomie, zaś demokraci chętniej widzieli w tym obszarze cięcia ${ }^{62}$. Konflikty polityczne nabrały największych rumieńców zdecydowanie pod koniec lipca 2011 r., kiedy to groziło USA... nieuchwalenie budżetu federalnego.

Z kolei przykładem ponadpartyjnego sojuszu w kwestiach dotyczących polityki zagranicznej może być bardzo zaawansowany projekt „ustawy Magnitskiego” (Sergei Magnitsky Rule of Law Accountability Act of 2012). Na mocy tego aktu prawnego rząd

62 Gwoli ilustracji, ze spraw bieżących, warto zauważyć, że 18 maja 2012 r. Izba Reprezentantów przyjęła projekt budżetu wojskowego na rok budżetowy 2013 (National Defense Authorization Act), co prawda bezpieczną większością 299 do 120, lecz wśród przeciwników aż 104 (czyli około 85\%) to kongresmani demokratyczni. 
USA może wprowadzić ograniczenia wizowe i finansowe wobec rosyjskich urzędników mających związek ze śmiercią zatrzymanego prawnika funduszu inwestycyjnego Hermitage Capital Siergieja Magnitskiego. W chwili pisania tekstu jest to kwestia, która może być traktowana jako jedna z najbardziej palących w stosunkach amerykańsko-rosyjskich. Potwierdzeniem takiej konstatacji mogą być choćby wypowiedzi prezydenta Putina, które zawierają możliwość wprowadzenia odpowiednich restrykcyjnych uregulowań wobec obywateli USA ${ }^{63}$.

\section{ELEMENT PROGNOSTYCZNY}

Stawianie prognoz w polityce jest zawsze działaniem karkołomnym. Niemniej jednak można pokusić się o pewien zarys takiej perspektywy. W tym celu sięgnijmy po dane dotyczące struktury wydatków budżetowych USA.

Według obliczeń sporządzanych przez Office of Management and Budget wydatki zarówno na sprawy międzynarodowe, jak i obronność miałyby charakteryzować się podobną dynamiką: spadek w najbliższych dwóch latach budżetowych, a następnie stabilizacja na poziomie około $+5 \mathrm{do}-5 \%$ (zob. wykres 1 ). Jak zatem widać, są to scenariusze dosyć ostrożne w tym sensie, że nie przewidują zaistnienia jakichkolwiek rewolucyjnych, radykalnych i jednocześnie trwałych zmian poziomu wydatków.

Wykres 1. Przewidywana zmiana wydatków budżetowych USA na sprawy międzynarodowe i obronność w latach 2011-2022; dane w procentach rok do roku

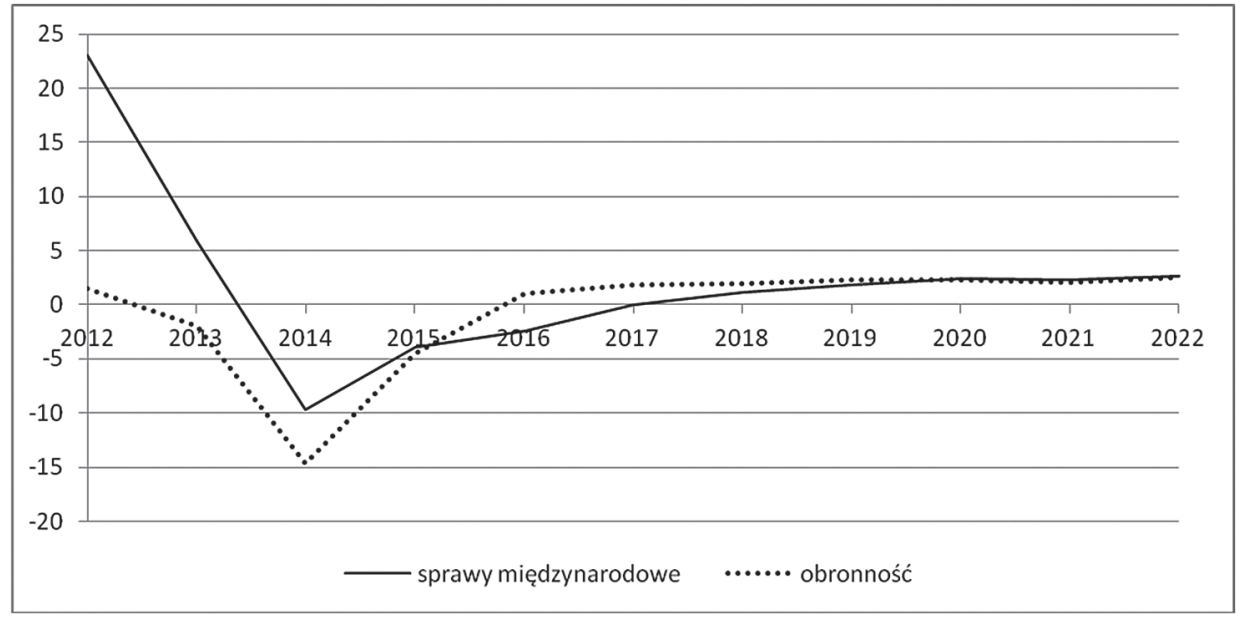

Źródło: opracowanie własne na podstawie oficjalnych danych rządowych: [online] http://www.whitehouse.gov/sites/default/files/omb/budget/fy2013/assets/32_1.pdf, 23 V 2012.

63 Zob. choćby słowa Władimira Putina wygłoszone w czasie konferencji prasowej na zakończenie szczytu G20 w Los Cabos w Meksyku w dniu 19 czerwca 2012 r.: [online] http://www.reuters.com/ article/2012/06/20/us-g20-putin-rights-idUSBRE85I1UX20120620, 27 VI 2012. 
Zasygnalizowane $\mathrm{w}$ powyższym tekście problemy wydają się skłaniać ku generalnemu wnioskowi, który brzmiałby następująco. Ze względu na rozwiązania instytucjonalne, uwarunkowania personalne oraz determinanty ideowe amerykańska polityka zagraniczna odznacza się daleko idącą kontynuacją, ciągłością w sferze priorytetów. Pojawiające się - co przecież nieuniknione - zmiany są raczej incydentalne i dotyczą kwestii względnie drugoplanowych lub też skupiają się na sposobie działania. W tej ostatniej kwestii (instrumenty) warto podkreślić, że sytuacja jest znacznie bardziej skomplikowana, niż zdaje się sugerować utrzymywany wizerunek dość jednolitej administracji, która sprzyjać miała rozwiązaniom pokojowym w przeciwieństwie do swoich poprzedników w latach 2001-2009. A zatem, jeżeli można mówić o zmianie, to jej charakter jest znacznie bardziej skomplikowany, niż można wywnioskować po lekturze niektórych analiz czy też po wysłuchaniu tylko wybranych wypowiedzi członków administracji. Pierwsza administracja Baracka Obamy wcale nie była wyjątkiem od tej zasady. Niezwykle intrygująco przedstawia się też w tym kontekście pytanie o to, jak będzie wyglądała amerykańska polityka zagraniczna w czasie drugiej - ostatniej - kadencji obecnego prezydenta. Jest to jednak temat do osobnej analizy, która może powstać za niecałe cztery lata.

\section{BIBLIOGRAFIA}

Barkley A.W., That Reminds Me, Garden City-Doubleday 1954.

Baumgartner F.R., Jones B.D., Agendas and Instability in American Politics, Chicago 2009.

Carlsnaes W., On Analysing the Dynamics of Foreign Policy Change. A Critique and Reconceptualization, „Cooperation and Conflict” 1993, Vol. 28, nr 1, s. 5-30, [online] http:// dx.doi.org/10.1177/0010836793028001001.

Davis M., He's No Ronald Reagan, „The Weekly Standard” 2011, 7 XII, [online] http://www. weeklystandard.com/blogs/hes-no-ronald-reagan_611705.html, 20 X 2012.

Foreign Policy Restructuring. The Politics of Continuity and Change in U.S. Foreign Policy, eds. J.A. Rosati, J.D. Hagan, M.W. Sampson, Columbia 1994.

Gibson D., New White House Staffers, Cecilia Munoz And Jacob Lew, Have Strategic Catholic, Jewish Ties, [online] http://www.huffingtonpost.com/2012/01/10/white-house-cecilia-munoz-jacob-lew_n_1197664.html, 20 X 2012.

Goldmann K., Change and Stability in Foreign Policy. The Problems and Possibilities of Détente, Princeton 1988.

Gustavsson J., How Should We Study Foreign Policy Change?, „Cooperation and Conflict” 1999, Vol. 34, nr 1, s. 73-95, [online] http://dx.doi.org/10.1177/00108369921961780.

Hermann Ch.F., Changing Course. When Governments Choose to Redirect Foreign Policy, „International Studies Quarterly” 1990, Vol. 34, nr 1, s. 3-21, [online] http://dx.doi. org/10.2307/2600403.

Indyk M., Lieberthal K., O’Hanlon M.E., Scoring Obamas Foreign Policy. A Progressive Pragmatist Tries to Bend History, „Foreign Affairs” 2012, May/June, [online] http://www.foreignaffairs.com/articles/137516/martin-indyk-kenneth-lieberthal-and-michael-e-ohanlon/scoring-obamas-foreign-policy, 3 VII 2012. 
John P., Margetts H., Policy Punctuations in the UK. Fluctuations and Equilibria in Central Government Expenditure since 1951, „Public Administration” 2003, Vol. 81, nr 3, s. 411 -413, [online] http://dx.doi.org/10.1111/1467-9299.00354.

Jones B.D., Baumgartner F.R., True J.L., Policy Punctuations. U.S. Budget Authority, 1947-1995, „Journal of Politics” 1998, t. 60, nr 1, s. 1-33, [online] http://dx.doi. org/10.2307/2647999.

Jones B.D., Sulkin T., Larsen H.A., Policy Punctuations in American Political Institutions, „American Political Science Review” 2003, Vol. 97, nr 1, s. 151-169, [online] http://dx.doi. org/10.1017/S0003055403000583.

Katzman K., Iran. U.S. Concerns and Policy Responses, Congressional Research Service, Washington, DC 2012, 23 III, [online] http://www.fas.org/sgp/crs/mideast/RL32048. pdf, 7 IV 2012.

Lynch T.J., American Foreign Policy in the 2010s, [w:] Developments in American Politics, eds. G. Peele [et al.], New York 2010, s. 220-237.

Łoś-Nowak T., Polityka zagraniczna - state i zmienne komponenty procesu formutowania i realizacji, [w:] Polityka zagraniczna. Aktorzy, potencjaty, strategie, red. nauk. tejże, Warszawa 2011, s. 42-58.

McCrummen S., Clinton, in Kabul, Declares Afghanistan a Major U.S. ally, „The Washington Post” 2012, 7 VII, [online] http://www.washingtonpost.com/world/asia_pacific/clinton-in-kabul-declares-afghanistan-a-major-us-ally/2012/07/07/gJQAj3VDTW_story.html, 8 IX 2012.

Nau H.R., Obama's Foreign Policy. The Swing Away from Bush. How Far to Go?, „Policy Review" 2010, April/May, [online] http://www.hoover.org/publications/policy-review/article/5287, 12 VI 2012.

Oren I., Why Has the United States Not Bombed Iran? The Domestic Politics of America's Response to Iran's Nuclear Programme, „Cambridge Review of International Affairs” 2011, Vol. 24, nr 4, s. 659-684, [online] http://dx.doi.org/10.1080/09557571.2011.630382.

Parmar I., American Power and Identities in the Age of Obama, „International Politics” 2001, Vol. 48, nr 2-3, s. 153-163, [online] http://dx.doi.org/10.1057/ip.2011.10.

Pietraś Z.J., Koncepcje adaptacji politycznej, [w:] Mechanizmy adaptacji politycznej państwa, red. Z.J. Pietraś, A. Dumała, Lublin 1990, s. 123-158.

Policy Dynamics, eds. F.R. Baumgartner, B.D. Jones, Chicago 2002.

Richter P., Hillary Clinton to Table Human Rights Issues in China Talks, „Los Angeles Times” 2009, 21 II, [online] http://articles.latimes.com/2009/feb/21/world/fg-clinton-china21, 22 V 2012.

Rosenau J.N., The Study of Political Adaptation, London-New York 1981.

Szklarski B., Przywództwo polityczne między rządzeniem a reprezentacja, [w:] Amerykańska demokracja wXXI wieku, red. A. Mania, P. Laidler, Kraków 2006.

Wallerstein I., Koniec świata jaki znamy, przeł. M. Bilewicz, A.W. Jelonek, K. Tyszka, Warszawa 2004, Spoteczeństwo Wspótczesne.

Welch D.A., Painful Choices. A Theory of Foreign Policy Change, Princeton 2005.

Why Nations Realign. Foreign Policy Restructuring in the Postwar World, ed. K.J. Holsti, London-Boston 1982. 
Wildavsky A.B., The Politics of the Budgetary Process, Boston 1964.

Wilson S., DeYoung K., NATO Leaders Agree on Framework to Wind Down Afghan Mission, „The Washington Post” 2012, 21 V, [online] http://www.washingtonpost.com/world/ national-security/obama-other-nato-leaders-begin-crucial-summit-on-afghanistan/2012/ 05/21/gIQArWJYfU_story.html, 8 IX 2012.

Dr Łukasz WORDLICZEK, adiunkt w Instytucie Amerykanistyki i Studiów Polonijnych UJ, doktor nauk politycznych; działalność dydaktyczna (w języku polskim i angielskim) obejmuje zagadnienia dotyczące amerykańskiego i polskiego systemu politycznego oraz amerykańskiej polityki zagranicznej; zainteresowania badawcze koncentrują się wokół mechanizmów kontynuacji i zmiany w polityce, zasady podziału władzy, funkcjonowania zasady reprezentacji oraz zagadnień metodologicznych. Jest autorem, redaktorem lub współredaktorem siedmiu książek, a także autorem artykułów oraz wystąpień konferencyjnych w języku polskim i angielskim. 